\title{
A Reanalysis of Social - Cultural Impacts and Functions of Worship: A Case Study on Salah (Namaz)
}

\author{
Mahmoud Reza Farrokhian \\ P.H.D student of Jurisprudence and Islamic Law at Islamic Azad University, Jahrom Branch, Iran \\ Dr. Abdulhamid Arefian \\ Faculty Member of Islamic Azad University, Jahrom Branch, Iran
}

\section{Gholmreza Saber Jahromi}

Doctor of Philosophy in Tehran universitydiviny Iran Corresponding Author Email: nf.shahid1363@Gmail.com

\section{Doi:10.5901/mjss.2016.v7n4s1p249}

\begin{abstract}
The sacred religion of Islam has imposed certain religious duties on its followers of which some are obligatory and some are just recommended, this is done for the sake of spiritual nourishment and growth of Islam followers. Salah (namaz) is an important obligatory type of worship that is crucial for self growth and getting closer to God. That is why we have chosen to analyze the quality, levels and orders of Salah (Namaz) in order to rediscover Islamic teachings, and contribute to spiritual growth of society. Descriptive- analytic methods were applied in this study. The study tends to answer questions such as: what are the social and cultural functions of Salah (namaz) and what we can do to optimize those functions? Salah, apart from its content helps people and societies to better themselves, based on its conditions and rules. This study had identified items such as: crime rate reduction, charitable attitude, kindness, discipline, justice seeking, social equality seeking and respecting other's rights to be the cultural and social impacts of Salah. Thus this act of worship might help optimize the mentioned qualities in a society,
\end{abstract}

Keywords: Worship; Salah (namaz); Function; Culture

\section{Introduction}

Islamic civilization was created due to the culture, traditions, ethics and rules elicited from the heart of Islam. The religion of Islam is based on harmonious sets of teachings which regulate political, cultural and economic sectors. In other words, every action taken should be a reflection of Islamic rules and, laws. Perhaps the greatest impact of religions is on the culture of a society, religious traditions and worships lead to certain cultural behaviors. For example, in religious gatherings people get to know each other and cultural exchange might take place during these interactions. A human's faith and sets of beliefs are the building blocks of his or her identity. People's identity optimizes the social dimensions of a society such as: order and security. Religious patterns and structures can form a human's social identity. Thus religions have an identity building nature. As food is necessary for the nourishment of our bodies, religious tasks and traditions (soul foods) are important for the nourishment of our spirits (Hamilton, 2011, p 178). Since religion is a life plan, thus its impacts and functions on people and societies' life would be inevitable, if this wasn't the case then what was the point of practicing religion after all? Salah (namaz) as a summary of Islamic religion shows the way to real Muslims and points out their duties and responsibilities to them. As the Prophet of Islam points out:" Salah (namaz) should be a priority to every Muslim for it is the greatest of worships," (Deilami, 1998, p 38). The objective of stating the functions of worships is to recognize the religious life plan, developing religious culture and creating awareness about factors of spiritual progress, growth and nourishment in life, and also motivating people to move toward infinity. 


\section{Concepts and Principles}

\subsection{Concept Terminology}

First, we take a look at the terminology of concepts such as worships, Salah, culture and functions in order to reach study's objectives effectively. Then, we explain the conditions under which worshiping becomes obligatory for Muslims.

\subsubsection{Worship}

The definition of worship in the book of Altahqiq has been quoted from literates as "the act of humility, subjection and obedience, as a matter of fact the word worshiping means showing obedience and humility towards God," (Mostafavi, $1981,8^{\text {th }}$ vol. p 13). Thus the concept of worship can be defined in accordance to the above definition as" Giving up to the idea that I am not in control of my life and accepting that some other entity decides for me and I should always be humble and obedient towards him." Anything done for the sake of God can be considered as worship and might help bring people closer to Lord. Thus any humane daily chore can be considered as an act of worship which would bring

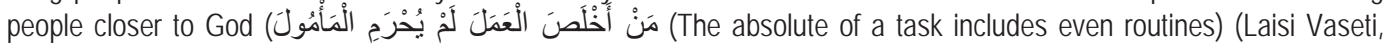
1997, p 443).

\subsubsection{Salah (Namaz)}

The Persian word Namaz refers to the acts of bowing, homage and worship (Toisarkani , 1983, p 443), this word was gradually used to describe the act of worshiping God (Salah prayer) by Muslims. The root of the Arabic word Salah would be (Salwat) which means admiring beauty, saluting, worshiping holy entities, etc. Some consider this word to have the same root as the word (sala) which means bringing closer and sacrificing to fire. (Mostafavi 1981, p 319). The word Salah itself refers to the act of praying to god (Salah Prayer). Thus a committed Muslim should pray to lord through Salah prayer 3 to 5 times a day, In other words Muslims ask God's help and expect a decent life from him. The holy Quran doesn't use the phrase "saying Salah prayer" but rather refers to its establishment, in other words Salah prayer can be treated as a silent action, and it is true that some encyclopedias interpret Salah (namaz) as prayer but those interpretations only refers to its literal aspect along with mind focus and emotional availability.

\subsubsection{Culture}

Culture translates to the word Farhang in Persian, this word is compound and consists of two parts of Far + Hang (Amid, 1983, p 953). There are numerous interpretations available for the concept of culture (Farhang), sometimes this word would refer to things such as: literacy, knowledge, wisdom, set of customs and literary and scientific works of a nation, dictionary, goodness, higher education, virtue, glory, art, a tree branch laid and buried into the soil as well as education and training and school of thought or ideology (Sahebi, 2006, p 84). In other words, culture is amongst the most comprehensive concepts of social sciences which can be defined and interoperated in various ways. Social sciences literature refers to culture as: literacy or customs and traditions that each person in a society is willing to receive and follow (Husaini Dashti, 2007, on the word: culture). Other definitions of culture describe this concept as: sets of sciences, knowledge. Arts, thoughts and opinions, ethics, rules and regulations, customs and traditions (Saiedian , 2002. on the word: culture). Thus, one can define culture as a set of distinct traits and characteristics that could include art, literature, lifestyles, coexistence methods, valuable systems, customs and beliefs (Farahani, 2007). In other words, culture refers to sets of knowledge, beliefs and opinions, motivations, ethics, values, arts, habits, customs and traditions that are embedded in a society and have distinct and contagious boundaries, and the word function refers to what task we expect from each single object to perform. .

\section{Obligation Conditions}

Human beings of all entities have the ability to tend to their obligations which are advantages and a god given gifts. Obligation means that one should perform certain tasks, and recognize one's responsibilities, because God wants one to do so. Thus the act of worship is obligatory for those who meet the following conditions: 


\subsection{Puberty}

Puberty is considered to be the time in life, when a boy or girl becomes mature. When a boy turns 15 and a girl turns 10 , they reach the age of puberty; therefore they should tend to all religious obligatory tasks and avoid sinful ones, so if a mature person would engage in sinful behaviors he or she would be punished by God. Although puberty is technically the true obligatory condition, but it is recommended that parents raise their kids in such way that they are familiar with and willing to perform Salah and other types of worship from a very young age, thus when they reach the actual age of puberty they would be already aware of all religious rules and regulations.

\subsection{Physical Strength}

Having physical strength is another obligatory condition. Our just Lord never expects his followers to do something beyond their capacity. As God points out in Quran's Baqarah Surah" Our lord does not make us bear that, for which we have no strength."

\subsection{Freedom of Choice}

Freedom of choice is also an obligatory condition. If one fails to perform one's obligatory religious duties due to pressure and coercion then one's sin is forgiven in the eyes of God. An idolatrous regime banning its people from going to Hajj, or a cruel person forcing a man to break his fast are good examples for that.

\subsection{Soundness of Mind}

Human's mind distinguishes him from animals, thus its soundness is another obligatory condition. The insane and mentally ill is excused from tending to his or her religious duties. The importance of this aspect is as such that God has banned all factors that would deter a person's soundness of mind (such as: alcohol consumption) and has recommended activities that would optimize it (such as: gaining knowledge, seeking advice, gaining experience etc).

\section{Worship Quality}

The act of worship consists of different levels depending on its content, intention, quality and personal characteristics of worshipers. Sometimes, an act of worship is mechanical and is only following the rules (Acceptable level) and sometimes it is done with the full focus of the heart and mind (Perfection level). Worship and especially Salah (Namaz) have various social and cultural functions apart from their content. Therefore, high quality worship might enhance and optimizes the mentioned functions. The analysis of Salah's (namaz) functions in regard to its quality are as follows:

\subsection{Hard Conditions for Worship}

Good intentions and following the worship's guidelines are 2 important factors for its validity. In other words, worship should be performed only for god's sake and for obeying his rules, but when it is done for attention seeking purposes or hypocritical reasons it would be considered invalid even if it is in accordance with guidelines. As Imam Sadeq points out:" (Quran, 2nd vol. p 162) the verse translates to "An honest task is one that does not seek apperception or adulation from anyone but God." In other words anything you do should be in accordance with sharia law not the latest trends and fads that some people tend to appreciate. Each single movement of Salah (e.g. how to say Salah (namaz), where should it be recited slowly, when should one sit? when to stand? Where to pray 4 postures of Salah? Where the 2 postures are recommended? Etc) should be in accordance with sharia law.

\subsection{Conditions for Worship Validity}

Following all the conditions for worship validation would not only make the act of worship in accordance with its related law, but would also bring the worshipper closer to God. Sometimes Salah might be correct technically but would not lead into spiritual growth, that prayer would be like a medication that does not cure the ailment, or a commodity for which there is no buyer. Some people consider worshiping only as a way to escape from punishment but there is much more to it than that, a true worshipper is favored by God, thus God might answer his prayers. 
The following sections cover the insights offered in Quran verses and ahadith on validation of worship and good deed. It is worth mentioning that the following insights can be treated as cultural and social functions of worship:

\subsubsection{Faith}

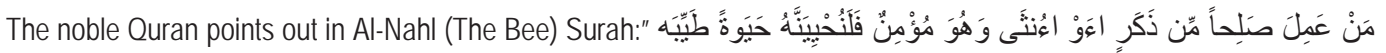
which translates to:" Anyone who does righteous deeds and is a believer shall we most certainly cause to live a good life,"

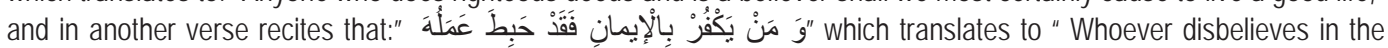
oneness of Allah and in all the other articles of faith then his work is fruitless and at hereafter he will be among the losers."

\subsubsection{Authority (Walayah) Acceptance}

What makes a deed righteous is highly related to accepting a divine authority and leadership. It is under the shadow of such leadership that the deeds become righteous and worship becomes useful, if one would hesitate to accept a divine authority figure or leader then his good deeds would turn into evil and his worship would be futile, useless and in accordance with the agenda of enemies of the God's way. Therefore, God only accepts such worship that is under the

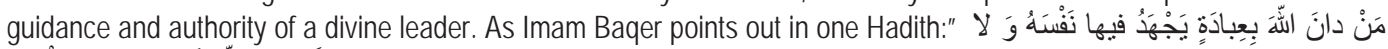

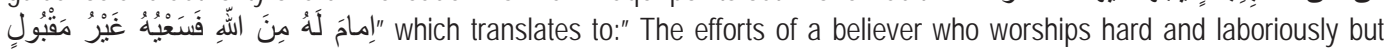
doesn't believe in an Imam appointed by God are fruitless and in vain.," (Kalini , Q 1407, vol1 , p 183). Another Hadith

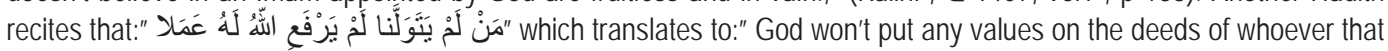
refuses to accept our guardianship and authority. " (Kalini , Q 1407, vol1 , p 430) .

\subsubsection{Tending to Disadvantaged People}

The poor and needy is also the God's servant. Such worship that is not accompanied by tending to disadvantaged and poor servants of God would be of no value. The concepts of Salah (namaz) and Zakat (religious tax) are not separate from each other, one refers to communication with God and the other refers to the same with his servants. It is quoted

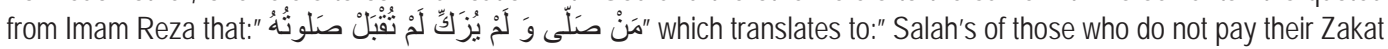
bears no validity, (Al-Arousi , Al- Havizi, q 1415, vol.1 , p 74)"Yes! If one would hesitate to pay the disadvantaged their well deserved money, then one's way of life would be evil and unjust.

\subsubsection{Kindness}

Brotherhood, unity and kindness are the pillars of an Islamic society. Whatever that might break up this brotherhood and unity and would turn kindness into conflict, might make worship validity difficult as well. Unity and brotherhood can be broken up by means of defamation, accusation, causing divide, mistreatment and unkind actions, hurting people or refusing to socialize. On the contrary, socializing, good intentions and helping fellow human validate the good deeds and prayers.. Although there are numerous ahadith on this subject but Prophet Muhammad's :" God would not accept the prayer and fasting of whoever talks behind a Muslim's back for as long as 40 days. , unless the person forgives his accuser," stands above them all, (Shoeiri, Bita, p 146).

\subsubsection{Respecting other's Rights}

Another impact of Salah is that it makes people respect each other's rights, The school of Islam advices a person who practices Salah (namaz) not to use any item that belongs to someone else without his or her consent in the process of Salah ,in order to accentuate the importance of showing sensitivity toward other's social rights among Muslims. As the martyred teacher Morteza Motahari points out:" Islam tells us that we should not establish Salah where its owner does not consent us to do so, we should not prepare for Salah with the water whose owner does not consent us to use , in other words everything used for the process of Salah should be fully consented. Even if there is a string of thread on your clothes that does not belong to you and its owner does not consent it to be there, then your worship and prayer is of no use and futile. Therefore the place, clothes and water used for Salah should be fully consented; otherwise the Salah would not be valid. 


\subsubsection{Discipline and Consistency}

It is better for a worship to have a permanent and orderly schedule. Following Islamic rules brings order and discipline into people's lives. Salah awaken the spirit of order and discipline in a person and being consistent at it embeds this consistency into a person's soul. Every Muslim should offer Salah 5 times a day. The on time establishment of Salah is highly recommended. As Imam Ali points out:" A faithful person should divide his or her days into 3 parts , one for prayers and worship , one for earning a living and one for getting used to solitude which is the most beautiful of them all," (Deilami, 1997 p 295). Engagement in the religious ritualistic act of Salah makes a person more disciplined and organized. A committed Salah establisher will learn the value of order and consistency at other tasks as well. Since Salah should be offered on certain times of day, thus it might teach the values of time management to people. Since a person agrees to establish Salah in accordance with its rules, thus he or she might accept other rules of life more easily.

\section{Signs of Worship Validity}

Considering all the conditions and rules for worship validity thus one should be careful not to offer $t$ a useless Salah (namaz) or worship in vain. Performing duties alone is just not enough, one should make sure that one's prayer and

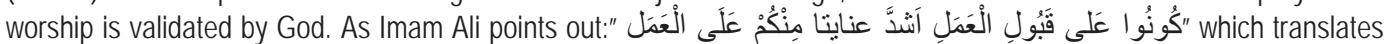
to:"One should focus on the validity of one's deed, not the deed itself!," (Sheikh Sadouq, 1983, Al-Hesal,vol 1, p 14 ). So how could one find out whether one's worship was valid or not?

\subsection{Crime Prevention and Reduction Function}

One of the social functions of Salah (namaz) would be its crime prevention and reduction impact. In other words, a true Salah establisher would be so close to God that the thought of committing a crime would not even cross his mind, this in

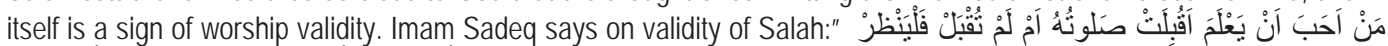

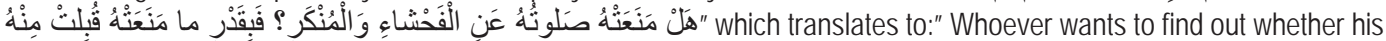
or her Salah was accepted or not should observe whether it has prevented him from committing sins and crimes or not," (Madjlesi, 1403, vol.16, p 205).)Salah purifies the mind, thus a Salah establisher is more likely to avoid sinful deeds. Since Salah reminds people of the greatest force of prevention thus Salah establishers are less likely to commit adultery and might resist temptations more than others. The noble Quran had also pointed out the social anomalous behavior

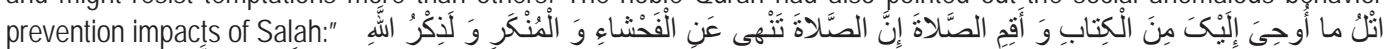

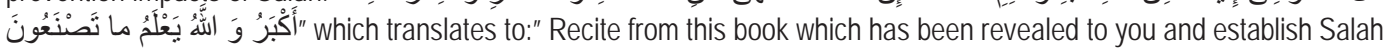
, surely Salah keeps one away from evil deeds and the remembrance of Allah (during your prayers and Allah's mention of your name in response to your prayers) is the greatest of all deeds. Allah knows what you do."(Al- Ankabout (The Spider) Surah: 45). The nature of Salah is in such way that reminds one of the afterlife, therefore it prevents and scares one away from evil deeds. Salah not only helps you to grow spiritually but also prevents you from committing shameful and evil deeds (Makarem Shirazi , 1992, vol.16, p 284). Crime rate in societies whose people establish Salah is considerately lower compared to Salah-free societies. As a matter of fact in holy months such as Ramadan, Rajab etc the crime rates would be cut down to half. Salah impacts its establisher one way or another, it is impossible for a Salah establisher not to experience its impact. Even if one establishes Salah for hypocritical reasons and is full of sin, Salah would still affect that person in some way (even though its effect would be considerably low in this case). It has been said that a youth who was famous for evil and sinful deeds was establishing his Salah behind Prophet Muhammad, when his followers informed the prophet of it he said:" Eventually Salah will prevent him from committing evil deeds." (Madjlesi, 1403, vol.79, p 198).

\section{Customs and Traditions of Salah (namaz)}

Standing before God requires a pure heart, good intentions and a God satisfying attitude, A deep familiarity with God, requires scholarly insight, a mouth not dirty with foul language and a face not frowned in disobedience to God's orders. One's heart and emotions should be present in the process of Salah. One should appear with a nice appearance before one's God. The customs of Salah are as follows: preparing for Salah (tasks one should tend to before the onset of Salah), Salah coincides (things one does during Salah) and Salah sequences (things one does after the establishment of Salah). Preparing for Salah consists of the following factors: 


\subsection{Cleanliness (Taharah)}

One of the functions of Salah would be its cleanliness promoting effect. If the preparation for Salah is not followed through correctly, then the Salah would be invalid. A Muslim should be particularly clean for the Salah. Wearing a nice dress and a pleasant perfume or a special ring (Aqiq) is also recommended. Sometimes a person can only be efficiently clean for Salah only by means of ablution or Ghusl (Bathing the whole body with water), if one has major impurities or Janabah (discharge of seminal secretions or sexual intercourse) then one should clean one's entire body by means of ablution (Ghusl). When there is no time for ablution with water, or when use of water is dangerous for a person dry ablution or Tayammum is used as its substitute. Concepts of ablution and dry ablution both consist of numerous aspects that tending to might drive us farther away from the objective of this paper.

\subsection{Dress Code for Salah}

The dress chosen for Salah should cover the whole body. Although, a man can establish Salah only by covering his private parts but it is customary for men to cover themselves from navel to knee. Women should cover their whole body (except for face, hands and feet) in order for their Salah to be valid. Dress chosen for Salah should be free from the slightest impurities and the color white is recommended for it. Wearing an aqiq ring or avoiding dirty, tight, black clothes is also customary for the processes of Salah.

Establishing Salah without proper clothes would not only invalidate it but would promote sinful deeds in society as well.

\section{Congregational Salah}

Congregated Salah is considered to have more social and spiritual benefit than individual Salah. Congregational Salah shows the glorious unity and brotherhood amongst Muslims and is one of the purest, simplest and cheapest gatherings in the world. Congregational Salah upsets Islam's enemies and is a factor for order, realizing values of time and fighting selfishness and individualism. The religious brotherhood is created in these gatherings. It is recommended that one should wait in order to establish a congregated Salah (Imam Khomeini, 1986, problem no. 1402). In congregated Salahs an Imam is appointed in order for others to pray behind him, the chosen Imam should be a scholar or the one who has the best knowledge of the Quran. Next sections cover the characteristic of Imams of congregational Salam.

\subsection{The Justness of (Congregational) Salah Imams}

Since congregational Salah is a religious gathering thus the person appointed as its Imam should be the best and purest man available among the worshippers. A sinful and irreligious person should never be appointed as Imam. As pointed out

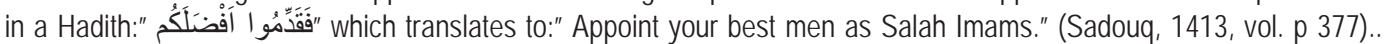
Justness is an internal state which keeps people from committing evil deeds or from repeating them (Qar'ati , 2007). When Imam Sadeq was asked about the characteristics of a just person, he replied :" A just person is one who covers his eyes when confronted with inappropriate scenes, stops his tongue from uttering foul language and keeps his hands from inflicting any harm," (Madjlesi 1403, vol 75. P 248). As Allah's prophet points out:" A just person is one whose trades are not fraudulent, whose words are nothing but the truth and who won't break his promise ," (Madjlesi 1403 vol. 67, p 1). Moreover, when Imams of congregational Salahs are just and pure, they might help to promote those characteristics within a society.

\subsection{Believers Getting Acquainted with each other and the Closeness of Hearts}

The nature of congregational Salahs is in such way that people might get acquainted with each other through these gatherings and it might have great consequence. Helping each other out, tending to each others' problems, building positive friendships. Creating strong family ties, rational marriages etc, might be some outcomes of these acquaintances Rows of congregational Salah are the healthiest, most emotional and simplest gathering for which we should thank the lord.

Those acquaintances create closeness of hearts between people. As Allah's prophet points out:" Rows of congregational Salah should be orderly and organized so it would create harmony in your hearts, keep in touch with each other for it promotes kindness and caring," (Motaqi Hendi, vol.7, p 623). As mentioned earlier, the presence of 
faithful people and believers in congregational Salah ceremonies makes for their acquaintances and consequently

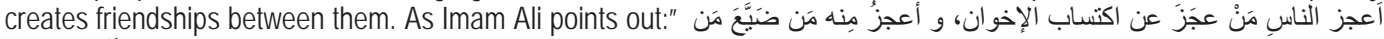

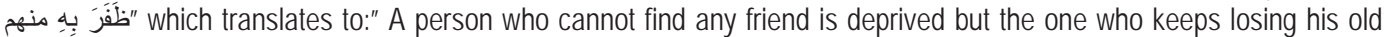
friends is the most deprived." (Sharif Al-Razi, 1414, p470). Believers' friendships bring them closer and might help to

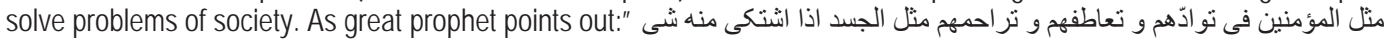
" تداعى له ساير الجسد بالسّهر و الحمّى "which translates to:" Friendships of believers is like organs of the body meaning the ailment of one affects all the others." (Payandeh, 2003.p 715). However, as a good friend might influence the other positively, a bad friend influences the other in negative ways. Quran states that when people go to hell they regret their

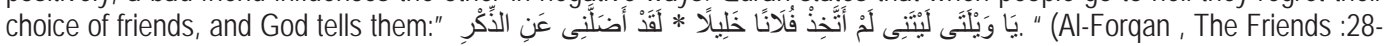
28)

\subsection{Optimizing the Spirit of Social Equality}

As scholar Muhammad Iqbal Lahouri (1877-1938), Pakistani poet and author beautifully points out:" The choosing of a single direction toward which people offer Salah in Islam was done in order to unify all Muslims in the world. Salah's form is designed in such way that all people offering it would appear equal regardless of their race or ethnicity. Therefore it optimizes the spirit of social equality in society. Just imagine what would happen if all Muslims would offer Salah shoulder to shoulder and with upmost unity! It would definitely create a spiritual revolution in all Muslim's hearts. As stated in Quran, people are only divided into race so they would be distinct from each other and that is all there is to it. The essence of Salah is to destroy obstacles dividing people, in a long lasting manner," (Iqbal Lahouri, 1967).

\section{Approaches for the Optimization of Salah Functions}

Since Salah is one of the main pillars of Islam and a way for expressing this religion, thus analyzing its functions and applications in political, cultural and social sectors is quiet necessary. The following 2 approaches are proposed for the optimization of Salah functions:

\subsection{Embedding Salah Culture}

From the perspective of religious teachings, lack of knowledge and awareness are the main reasons for the ignoring of

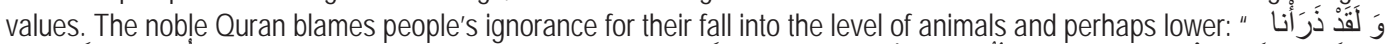

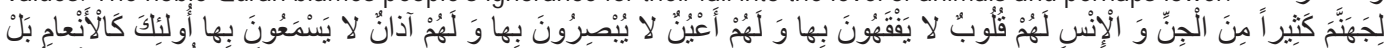

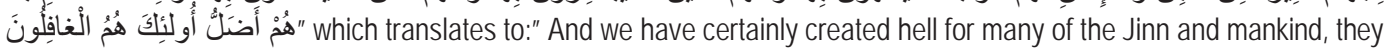
have hearts with which they do not understand, they have eyes with which they do not see, and they have ears with which they do not hear/. Those are like livestock, rather, they are more astray, and it is they who are the heedless." (AlAr'af : 179). Imam Ali had also identified ignorance as the main reason for committing evil deeds."( ظلمتُ نفسي و تجر أتُ بجهلي), (Tousi , 1411, vol. p 845). Spreading knowledge and awareness is the best way to fight ignorance. Sociologists argue that this can be done by mean of applying the following methods: 1 . Cultural acceptability 2. Social acceptability Sociologist believe that a human could never be apart from his or her society, Therefore, social acceptance refers to the process that teaches people how to survive in society and adjust to its norms (Mariji , 2011). The mentioned process impacts people in two different ways: sometimes groups and norms make a person socially acceptable person, other times, social life and coexistence makes a person socially acceptable in an unconscious manner (Cohen, 1993). If the process of social acceptability is consistent and continuous then people of a society would start to share many similarities and their values and norms would match with each other. In a society as such new members find their way and recognize norms and values more easily. This would promote cultural acceptability in a society (Bern , 2001, p 171). Spreading knowledge about Salah is the first step toward embedding its culture within a society. In order to do so people should gain knowledge and information about Salah and its impacts and advantages. Familiarizing people with the history and life of prophets and saints would also prove useful.

\subsection{Exploiting the Capacity of Media.}

The sensitive nature of culture accentuates the importance of using all facilities available in order to impact it. A refined culture is one which uses all means available to it, in order to push its agenda. Media are great tools for expanding the Islamic culture. Experts define Media as: The collective communication outlet or tool through which a message can be sent and received," (Mariji, 2005). Since media cover a wide geographical range and deliver messages to a vast number 
of people cheaply, thus their importance in mass communication cannot be ignored. Today, media is so powerful that can affect a society's culture from a place very distant to it. The capacity of media in its visual, hearing and written form should not be underestimated; producing valuable and regular TV programs about function of Salah can help people to recognize and appreciate them and consequently embed the culture of Salah in society.

\section{Conclusions}

Based on what was mentioned in the study we can conclude that Salah, as the most important religious duty is a summary of Quran and Islam, therefore it consist of all religious values and might impact a society's cultural and social sectors. Establishing congregational Salah promotes kindness and empathy in society and it is in such society that political, economic, social and cultural objectives are reached. Thus,. Salah is obviously the pillar of all religious plans,. Salah promotes spiritual growth regardless of its content. Tending to disadvantaged people, kindness, culture of order and sacrifice, justice seeking, seeking of social equality and respecting other's rights are among the numerous social and cultural functions of Salah. Therefore embedding Salah culture within a society might lead to optimization of the above characteristics.

\section{References}

The Noble Quran

Iqbal Lahouri, Muhammad, 1967, Reviving Religious Thoughts in Islam, Translated by: Ahmad Aram, Tehran, The center for Islamic publications and research

Bern, Aug , Nim, Ceff, (2001), Antecedents of Sociology , Translated by: Iraj Arian Pour, Gostardeh publication , Tehran , $3^{\text {rd }}$ edition

Payandeh, Abulqasem, (2003), Nahj- Al- Fasahah, (A Collection of Prophet's Ahadith) , Tehran, $4^{\text {th }}$ edition

Toisarkani, Muhammad Taqi, (1983), The Culture of Jaffari, University publication, Tehran

Hussaini Khameneie, Seyyed Ali, (2003), On the Depth of Salah, Farhange e Eslami Publications

Hussaini Dashty, Mustapha, (2006), The Comprehensive Islamic Encyclopedia, Tehran, Arayeh publications

Khomeini, Ruhullah,(1986), Toziha Al Masael (Problem Statement), Imam Ruhullah Mousavi Khomeini, Qom, Rouh publications

Deilami Hussaini, (1998), The Luminous Insights, Basij's Salah establishment center for public offices, Tehran

Deilami , Hassan Ibn Muhammad, (1997), Tabatabaie, Seyed Hassan, Guidance of Hearts, 1'st edition, Teacher Society, Qom, $2^{\text {nd }}$ edition,

Saiedian, Abdul Husain, (2003), The Novel and Vast Encyclopedia, Tehran, Elm va Zendegi publication, $4^{\text {th }}$ edition

Sharafi, Muhammad Reza, Muhammad, Sharif Pour, (2008), Role of Educational Institutions in Citizen Training : Cultural Engineering, March , April , p 52-53-54

Sharif Al Razi, Muhammad Bin Hassan, Nahj Al Balaqah , Qom , $1^{\text {st }}$ edition,

Shoeirie, Bita, Muhammad Bin Muhammad, Jama Al Akhbar, 1 15t edition , Najaf,

Sheikh Sadouq, (1413), Man La Yahzarah Faqih. , Teacher Society, Qom, $2^{\text {nd }}$ edition

AL Khesal, (1983), Teacher Society, Qom, 1st edition

Sahebi , Muhammad Javad, (2005), The Relationship Between Culture and Religion (Series of Papers), The Ministry of Culture and Islamic Guidance, Tehran

Tousi, Muhammad Bin Hassan , 1411, Mesbah A;I Mojtahed va Selah Al Motabed, Beirut, Intititue of Shite Jurisorudence, 1'st edition

Arousi Al havizi, 1415, Abd Ali Bin Jumah, Nour Al Theqlein Analysis. Ismailian, Qom, vol.1

Amid, Hassan, The Persian Dictionary, Tehran , Amir Kabir Publications,

Farahani, Fatimah, A Closer Look at UNSCO's Linguistic Diversity Conversion, Tehran, Culture, art and communication research center

Qarati, Mohsen, 2007, The Secret of Salah for Youth, The Cultural center of teachings of Auran

Kalini, Muhammad, Yaqoub bin Isaq, Al - Kaafi, Dar Al Maktab Islamieh, Tehran, 2th edition, vol 2

Cohen Bruce, (1993), The Basics of Sociology, Translated by: Qulam Abbas Tavassoli, Reza Fazel Zarandi, Tehran, Samt Publications

Laisi Vaseti, 1997, Ali Bin Muhammad, Oyoon Al Hokm Al Mavazo'. Dar Al Hadith publications, Qom,. 1st edition , p 443

Motaqi Hendi., Ali Bin Hessam Al Din, 1413, Kanz Al Amal Fi Senan Alaqval Alafaal , Beirut, Alreslah publications

Madjlesi, Muhammad Baqer, Bin Muhammad Taqi , 1403, Bahar al Anvar Al jamaiah Ladrar, Al akhbar Al a'emeh Al athar, Beirut , 2 ${ }^{\text {nd }}$ edition,

Mariji, Shamsullah, (2005), Analyzing the role of Family in Reducing Social Anomalies, social and cultural knowledge, 2nd year, no,. 4, p 49-72

Mariji, Shamsullah, (2005), The Mass Communication Media and Their Rule in Optimization and Reduction of Values, Knowledge Magazine,. No.91, p 19-35

Mostafavi, Hassan. (1981), Al Tahqiq Fi Kalamah Quran Al Karim , vol. 8-6, Translation and publication agency, Tehran

Makarem shirazi, Nasser, (1992), Sample Analysis, Islamieh Dar Al Maktab publication, Tehran, $10^{\text {th }}$ edition

Mousavi, Muhammad, (2008), Salah and Culture Development, Jum'ah Culture Monthly Magazine, no.71. p 58

Varam Bin abi Faras, Masoud Bin Issa, Varam Collection, Qom, 1'st edition, 1410Q, vol.2 